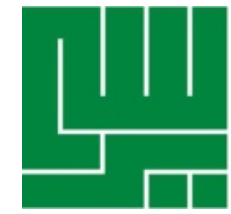

\title{
Efektivitas Self Monitoring untuk Meningkatkan Perilaku On-Task pada Anak dengan Attention Deficit Hyperactivity Disorder
}

\section{Effectiveness of Self Monitoring to Increase On-Task Behavior on A Child with Attention Deficit Hyperactivity Disorder}

\author{
Ezra Dessabela Isnannisa, Rini Hildayani
}

Fakultas Psikologi Universitas Indonesia

Email: ezradessabela@gmail.com

KATA KUNCI

KEYWORDS

ABSTRAK

ADHD, On-Task, Self Monitoring.

ADHD, On-Task, Self Monitoring.

Salah satu fitur utama anak dengan Attention Deficit Hyperactivity Disorder (ADHD) adalah kesulitan dalam mempertahankan perhatian. Hal itu berdampak pada kemampuan anak untuk mempertahankan perilaku on-task pada situasi belajar. Penelitian ini bertujuan untuk melihat efektivitas penerapan teknik self monitoring dalam meningkatkan perilaku on-task pada anak dengan ADHD. Penelitian ini menggunakan single subject design dengan desain penelitian A-B. Partisipan dalam penilitian ini merupakan anak laki-laki berusia sembilan tahun dengan ADHD predominantly inattentive. Penerapan self monitoring disertai pula dengan pembuatan self graph dan pemberian reinforcement. Evaluasi hasil penelitian dilakukan dengan membandingkan data saat sebelum dan setelah pemberian intervensi. Hasil penelitian menunjukkan adanya peningkatan kemampuan mempertahankan perilaku on-task yang signifikan, yaitu $25-35 \%$ sebelum pemberian intervensi menjadi $75-90 \%$ dari total durasi belajar selama 60 menit setelah pemberian intervensi. Hal tersebut mengindikasikan bahwa teknik self monitoring efektif untuk meningkatkan perilaku ontask pada anak dengan ADHD dan dapat menjadi alternatif intervensi yang dapat diterapkan untuk anak dengan ADHD pada situasi belajar di rumah.

Inattention is one of the main feature of children with Attention Deficit Hyperactivity Disorder (ADHD). It affects child's ability on sustaining on-task behavior on academic setting. This study uses single subject $A-B$ design and aims to investigate the effectiveness of self monitoring to increase on-task behavior on a child with ADHD. Participant of this study is a nine years old 


\begin{abstract}
boy with ADHD predominatly inattentive. The effectiveness of the program is evaluated by comparing pre-intervention and post-intervention data. The result shows significant increase in the ability to sustain on-task behavior, from 25-35\% at preintervention becomes $75-90 \%$ of total 60 minutes study duration on post-intervention. It is indicated that self monitoring technique appeared to be effective in increasing on-task behavior on a child with ADHD and can be applied as an alternative intervention for a child with ADHD on learning at home setting.
\end{abstract}

\section{PENDAHULUAN}

Atensi yang rendah sebagai salah satu fitur utama dari ADHD berdampak pada penyelesaian tugas atau kegiatan yang dilakukan oleh anak. Saat melakukan kegiatan atau menyelesaikan tugas, anak dengan ADHD mudah terdistraksi oleh stimulus lain sehingga sulit mengembalikan perhatian pada hal yang sedang dilakukan (Ross \& Randolph, 2014). Berdasarkan Costa dkk (2014), simtom inatentif merupakan dasar dari performa anak yang rendah di sekolah meski anak memiliki kecerdasan rata-rata.

Anak dengan ADHD memiliki masalah mendasar pada kemampuan meregulasi diri sehingga menunjukkan perilaku inatentif, hiperaktif, dan impulsif (Barkley, 1997; Semrud-Clikeman dkk, dalam Eggett, 2013), hal tersebut kerap mempengaruhi performa akademik anak (Reis, dalam Eggett, 2013). Secara lebih spesifik, Barkley (1997) mengemukakan teori self regulation yang menyatakan bahwa behavioral inhibition, executive function, dan sustained attention merupakan masalah utama pada anak dengan ADHD akibat adanya gangguan pada bagian korteks prefrontal pada otak. Hal tersebut mengakibatkan rendahnya kemampuan anak dengan ADHD dalam meregulasi perilakunya, termasuk tidak dapat mempertahankan atensi pada waktu yang lama dalam mengerjakan tugas (ontask).

Kesulitan mempertahankan perilaku on-task merupakan hal yang umum tampak pada anak dengan ADHD, sedangkan ADHD sendiri merupakan gangguan yang umum ditemui. Belum diketahui jumlah pasti anak dengan ADHD di Indonesia. Akan tetapi, berdasarkan survei yang dilakukan oleh Saputro (2009), diketahui bahwa prevalensi ADHD pada anak usia sekolah dasar di wilayah Jakarta saja mencapai $26,2 \%$.

Anak dengan ADHD seringkali mengetahui apa yang harus dilakukan, namun kesulitan mempertahankan atensi karena rendahnya behavioral inhibition (Barkley, 1997). Pada anak usia sekolah, perilaku on-task menjadi hal yang penting karena perilaku on-task terkait dengan penyelesaian, produktivitas, dan akurasi pengerjaan tugas yang berdampak pada keberfungsian dan pencapaian akademik anak (Amato-Zech, Hoff, \& Doepke, 2006). Pada anak dengan ADHD, kesulitan untuk menunjukkan perilaku on-task berdampak pada pencapaian akademik yang rendah. Untuk itu, intervensi yang menyasar pada kemampuan regulasi diri, dapat diimplementasikan pada anak dengan ADHD untuk meningkatkan perilaku ontask (Eggett, 2013).

Salah satu metode yang dapat diterapkan untuk meningkatkan perilaku on-task adalah self monitoring. Berbagai penelitian menunjukkan bahwa metode self monitoring efektif diterapkan untuk meningkatkan perilaku on-task, salah satunya pada anak dengan ADHD (Shapiro, Dupaul, \& Bradley-King, 1998; Eggett, 2013; DiGangi, Maag, \& Rutherford, 2014). Self monitoring merupakan teknik intervensi dimana anak diminta untuk mengobservasi target perilaku secara sistematis pada rentang waktu tertentu 
(Kazdin, 2013). Anak diminta untuk memantau perilaku dan membubuhkan checklist di lembar observasi jika perilaku yang diharapkan muncul pada interval waktu yang telah ditentukan (misal, setiap tiga menit selama 60 jam). Setiap interval waktu akan ditandai dengan sinyal berupa bunyi atau prompt dari orang lain. Self monitoring biasanya diterapkan bersamaan dengan pemberian reinforcement jika anak menunjukkan perilaku yang diharapkan. Hasil pencatatan oleh anak, nantinya akan dibandingkan dengan hasil pencatatan orangtua. Jika terdapat kesamaan hasil pencatatan, maka anak akan kembali diberi reinforcement. Selain melihat kesamaan hasil pencatatan, anak juga akan diberi masukan mengenai sesi yang telah dilakukan (Kazdin, 2013).

Secara umum, self monitoring atau kerap disebut pula sebagai self management, terdiri atas dua elemen, yaitu self observation dan self recording (Mace \& Kratochwill, dalam DiGangi, Maag, \& Rutherford, 2014). Anak diminta untuk mengamati perilaku dan melakukan pencatatan kemunculan perilaku on-task yang menjadi target. Selain itu, anak juga diminta untuk menuangkan data yang ia catat dalam bentuk grafik. Self graph merupakan salah satu bentuk dari self evaluation. Dengan melakukan self graph, anak dapat memantau perkembangan kemunculan perilaku on-task yang ia lakukan dari waktu ke waktu. Hasil yang dapat dipantau dengan mudah dalam bentuk grafik juga membantu meningkatkan motivasi anak untuk melakukan perilaku on-task (DiGangi, Maag, \& Rutherford, 2014).

Pada penelitian ini, partisipan merupakan anak laki-laki yang didiagnosis ADHD predominantly inattentive. Ia memiliki kecerdasan yang tergolong ratarata dan kemampuan yang baik dalam memahami pelajaran. Akan tetapi, atensinya sangat mudah teralihkan sehingga ia kerap tidak mengerjakan dan menyelesaikan sesuai harapan. Saat diingatkan oleh orangtua atau guru ia akan berusaha kembali fokus pada tugas yang sebelumnya ia kerjakan, namun keberadaan orang lain yang dapat mendampinginya belajar tidak selalu ada. Anak juga memiliki kesadaran dan keinginan yang besar untuk dapat fokus menyelesaikan tugas secara mandiri. Hanya saja, ia tidak dapat menyelesaikan tugas karena kesulitan mempertahankan atensinya. Terkait kondisi tersebut, self monitoring dinilai tepat untuk diterapkan pada anak ini karena self monitoring dapat menurunkan ketergantungan anak terhadap pengawasan orang lain dalam menunjukkan suatu perilaku (Amato-Zech, Hoff, \& Doepke, 2006).

Berdasarkan Rhode (dalam Shapiro, DuPaul, \& Bradley-Klug, 1998), terdapat 5 tahap yang dapat dilakukan dalam melaksanakan intervensi self monitoring, yaitu (1) baseline, (2) pencatatan oleh orang lain, kemudian anak diajak untuk mengevaluasi hasil pencatatan orang lain, (3) matching (anak mulai melakukan pencatatan sendiri, kemudian membandingkan catatannya dengan catatan orang lain), (4) fading (pengurangan pembandingan pencatatan anak dengan orang lain), dan (5) complete selfmanagement (anak melakukan self monitoring tanpa membandingkan catatan dan dievaluasi oleh orang lain).

Literatur mengenai penerapan teknik self monitoring pada anak dengan ADHD di Indonesia masih sangat terbatas. Terdapat beberapa penelitian yang mengkaji teknik self monitoring (Angelia, 2014; Jembarwati, 2015; Suryanti, 2015), namun penelitian-penelitian tersebut dilakukan pada populasi anak dengan perkembangan tipikal serta mengukur variabel selain perilaku on-task. Banyaknya kasus anak dengan ADHD di Indonesia menunjukkan pentingnya alternatif intervensi yang dapat diterapkan untuk mengatasi kesulitan yang dialami oleh anak dengan ADHD dalam mempertahankan fokus di situasi belajar. Berdasarkan hal tersebut, penelitian ini dilakukan untuk mencari tahu lebih lanjut mengenai efektivitas penerapan teknik self 
monitoring untuk meningkatkan perilaku on-task pada anak dengan ADHD.

\section{METODE PENELITIAN Desain Penelitian}

Desain penelitian yang digunakan dalam penelitian ini adalah single subject design dengan satu partisipan $(\mathrm{N}=1)$. Desain penelitian dengan satu partisipan umumnya dilakukan untuk melihat perbandingan kondisi partisipan saat sebelum dan setelah diberikannya intervensi (Gravetter \& Forzano, 2009).

\section{Partisipan}

Partisipan dalam penelitian ini adalah anak laki-laki usia sembilan tahun satu bulan. Ia didiagnosis ADHD predominantly inatttentive, enambulan sebelum dilaksanakannya penelitian. Berdasarkan hasil pemeriksaan psikologis yang sebelumnya dilakukan oleh peneliti, ditemukan sejumlah simtom inatentif pada anak yaitu, anak gagal dalam melihat detail atau ceroboh dalam menyelesaikan tugas dan kesulitan mempertahankan perhatian atau mudah terdistraksi. Ia kerap tidak menyelesaikan tugas yang diberikan karena cepat kehilangan fokus. Anak juga kesulitan untuk mengorganisasikan penyelesaian tugas. Ia kerap mengerjakan hal lain selain yang diinstruksikan dan memiliki manajemen waktu yang buruk dalam pengerjaan tugas. Ia juga sering kehilangan barang terutama alat tulis, serta cenderung menghindar dan mudah menyerah ketika menghadapi hal yang dianggap sulit.

Tes inteligensi terhadap anak menunjukkan bahwa kecerdasan anak berfungsi pada taraf rata-rata, atau dengan kisaran IQ 98 berdasarkan Skala Wechsler. Ia memiliki kemampuan yang baik dalam memahami pelajaran. Anak juga menunjukkan motivasi untuk menyelesaikan tugas dan keinginan untuk dapat mengelola diri dalam menyelesaikan tugas. Akan tetapi, atensi anak sangat mudah teralihkan. Anak juga merasa dirinya butuh dibantu untuk mengelola dirinya secara mandiri untuk menyelesaikan tugas.

\section{Variabel Penelitian}

Variabel yang diukur dalam penelitian ini adalah perilaku on-task. Berdasarkan Graham-Day, Gardner, dan Hsin (2010), definisi operasional dari perilaku on-task adalah mengerjakan tugas sesuai instruksi, memandang ke arah tugas, membahas hal yang berkaitan dengan tugas (bertanya atau menjawab seputar tugas), atau melakukan kegiatan lain terkait dengan penyelesaian tugas (membaca buku yang dibutuhkan dalam pengerjakan tugas). Hal yang tidak termasuk dalam perilaku on task yaitu, tidak mengerjakan tugas sesuai instruksi, membicarakan hal lain di luar tugas, melihat-lihat ke arah lain selama lebih dari tiga detik, berjalan-jalan, atau menggambar yang tidak ada hubungannya dengan tugas.

Anak dikatakan menunjukkan perilaku on-task jika pada rentang waktu tertentu, anak menunjukkan setidaknya satu dari perilaku yang tergolong on-task dan tidak menunjukkan satu pun perilaku offtask. Diharapkan anak dapat menunjukkan perilaku on-task selama minimal $60 \%$ dari total durasi satu jam.

\section{Instrumen Penelitian}

Data penelitian didapatkan melalui observasi dan wawancara. Instrumen penelitian yang digunakan dalam observasi adalah lembar pemantauan perilaku on-task yang diisi oleh peneliti serta lembar pemantauan self monitoring yang diisi oleh anak untuk memantau ada tidaknya perilaku on-task. Wawancara kepada ibu partisipan dilakukan untuk mengetahui kebiasaan belajar anak sehari-hari.

Pencatatan dilakukan dengan memberikan tanda checklist pada lembar observasi yang disediakan. Proses pencatatan akan dilakukan dengan bantuan stopwatch atau alarm. Interval tiga menit akan ditandai dengan adanya bunyi beep dari stopwatch atau dering alarm. Anak akan diminta untuk menandai perilakunya 
sebanyak 20 kali (setiap tiga menit selama 60 menit) pada lembar observasi. Pada saat yang bersamaan, peneliti didampingi ibu akan melakukan pencatatan perilaku ontask dengan interval waktu yang sama.

Lembar pemantauan baseline diisi dengan cara memberi tanda centang $(\checkmark)$ pada kolom on task atau off task, sesuai perilaku yang anak tunjukkan. Kolom perilaku on task akan ditandai apabila dalam rentang waktu tiga menit, anak menunjukkan setidaknya satu perilaku on task dan tidak menunjukkan perilaku off task sama sekali. Jika anak menunjukkan setidaknya satu perilaku off task, maka kolom off task yang akan ditandai.

Tujuan akhir dari program intervensi adalah anak mampu menunjukkan perilaku on-task minimal $60 \%$ dari total waktu belajar 1 jam, atau selama minimal 36 menit. Dengan begitu, diharapkan anak mendapatkan tanda checklist sebanyak 12 dari 20 kali pencatatan dalam satu sesi.
Pada tahap 2, 3, dan 4, anak juga akan diminta untuk menandai perilakunya pada lembar self monitoring dengan interval waktu yang sama. Pada akhir sesi, anak akan diminta mencocokkan hasil pencatatannya dengan hasil pencatatan peneliti.

\section{Prosedur Penelitian}

Sebelum melakukan penelitian, peneliti memeroleh gambaran perilaku anak melalui observasi anak dan wawancara orangtua. Peneliti kemudian melakukan functional behavioral assessment dengan mengindentifikasi hubungan antara antecedent, behavior, dan consequences (AB-C). Hal tersebut kemudian digunakan untuk merancang program modifikasi perilaku. Hasil functional behavioral assessment yang diperoleh dapat dilihat pada tabel 1.

Tabel 1

Hasil Functional Behavioral Assessment

\begin{tabular}{lll}
\hline \multicolumn{1}{c}{ Antecedent } & Behavior & \multicolumn{1}{c}{ Consequences } \\
\hline Tugas yang diberikan pada A (tugas & A mudah & Orangtua membiarkan dan tidak \\
rumah dari sekolah atau soal yang & terdistraksi & tahu apa yang harus dilakukan. \\
diberikan oleh orangtua) & dalam & Tugas tidak selesai \\
& mengerjakan & \\
& tugas & \\
\hline
\end{tabular}

Studi literatur dilakukan untuk merancang program intervensi yang disesuaikan dengan hasil functional behavioral assessment. Setelahnya, peneliti memberikan informed consent kepada partisipan dan orangtua, kemudian melakukan baseline selama empat sesi. Masing-masing sesi berlangsung selama 60 menit. Selama baseline, peneliti juga mengamati hal-hal yang ada di lingkungan yang menghambat kemunculan perilaku ontask pada anak dan melakukan kontrol terhadap hal-hal tersebut, seperti program intervensi akan dilakukan di meja belajar dan pintu yang ditutup untuk menghindari distraksi suara televisi dan menghilangkan benda-benda yang mendistraksi dari atas meja belajar.terhadap hal-hal tersebut, seperti program intervensi akan dilakukan di meja belajar dan pintu yang ditutup untuk menghindari distraksi suara televisi dan menghilangan benda-benda yang mendistraksi dari atas meja belajar.

Pada tahap pelaksanaan, program intervensi dijalankan selama 15 sesi yang dilaksanakan selama 15 hari pada hari senin hingga jumat. Setiap sesi berlangsung sekitar 60 hingga 90 menit. Selanjutnya, peneliti melakukan post test sebanyak empat sesi. Data yang diperoleh saat post test kemudian dibandingkan dengan data saat baseline untuk mengetahui dampak pemberian intervensi terhadap kemunculan perilaku on-task anak. 


\section{Program Intervensi}

Program modifikasi perilaku untuk meningkatkan kemunculan perilaku on-task pada anak menggunakan teknik selfmonitoring dan self graph, disertai dengan pemberian reinforcement. Pada teknik selfmonitoring, anak akan diminta mencatat kemunculan perilaku on-task dan off-task dalam interval tiga menit selama satu jam pengerjaan tugas di rumah. Pencatatan dilakukan dengan memberikan tanda checklist pada lembar yang disediakan. Proses pencatatan akan dilakukan dengan bantuan stopwatch. Interval tiga menit akan ditandai dengan adanya bunyi beep dari stopwatch.

Pada setiap sesi, peneliti akan mencatat kemunculan perilaku on-task atau off-task anak sebanyak 20 kali, yaitu setiap tiga menit selama 60 menit, pada lembar observasi. Tanda checklist dibubuhkan apabila dalam rentang waktu 3 menit anak menunjukkan setidaknya satu perilaku yang tergolong on-task dan tanpa menunjukkan perilaku off-task. Teknik lain yang digunakan adalah self graph. Pada setiap akhir sesi, anak akan diminta membuat grafik dari hasil pencatatan yang dilakukan. Pada tahap 1, anak akan membuat self graph berdasarkan hasil pencatatan peneliti, sedangkan pada tahap 2, 3, dan 4, self graph dibuat berdasarkan hasil selfmonitoring yang anak lakukan. Jika terdapat peningkatan pada grafik di setiap sesinya, anak akan mendapatkan reinforcement berupa sticker.

Sebelum membuat self graph, evaluasi akan dilakukan untuk menyamakan persepsi anak dengan peneliti mengenai perilaku on-task atau off-task yang muncul. Selain untuk menyamakan persepsi mengenai perilaku on-task dan off-task, evaluasi juga dilakukan bersama anak dengan cara mendiskusikan sesi yang dijalankan, serta apa saja yang perlu dilakukan untuk meningkatkan perilaku ontask.

Secara umum, pelaksanaan intervensi dilaksanakan selama 15 sesi yang terbagi menjadi empat tahap, sebagaimana dapat dilihat pada tabel 2 . 
Tabel 2

Program Intervensi

\begin{tabular}{|c|c|c|}
\hline Tahap & $\begin{array}{c}\text { Jumlah } \\
\text { Sesi }\end{array}$ & Prosedur \\
\hline \multirow[t]{4}{*}{1} & \multirow[t]{4}{*}{3} & Pencatatan hanya dilakukan oleh peneliti. \\
\hline & & $\begin{array}{l}\text { Di akhir sesi, dilakukan evaluasi hasil pencatatan } \\
\text { dan perhitungan jumlah on-task bersama anak. }\end{array}$ \\
\hline & & Pembuatan self graph. \\
\hline & & $\begin{array}{l}\text { Reinforcement: } 1 \text { stiker jika pada sesi } 1 \text { perilaku } \\
\text { on-task anak lebih tinggi dibandingkan dengan } \\
\text { rata-rata perilaku on-task saat baseline. Pada sesi } 2 \\
\text { dan 3, anak akan mendapat stiker jika terdapat } \\
\text { peningkatan perilaku on-task yang terlihat pada } \\
\text { grafik. }\end{array}$ \\
\hline \multirow[t]{4}{*}{2} & \multirow[t]{4}{*}{4} & Pencatatan dilakukan oleh peneliti dan anak. \\
\hline & & $\begin{array}{l}\text { Di akhir sesi, anak membandingkan catatannya } \\
\text { dengan catatan peneliti dan melakukan evaluasi } \\
\text { sesi. }\end{array}$ \\
\hline & & Pembuatan self graph. \\
\hline & & $\begin{array}{l}\text { Reinforcement: } \\
2 \text { stiker (peningkatan jumlah on-task), } 1 \text { stiker } \\
\text { (jumlah on-task sama dengan sesi sebelumnya), } 0 \\
\text { stiker (penurunan jumlah on-task). } \\
\text { Bonus } 1 \text { stiker (pencatatan anak sama dengan } \\
\text { peneliti, atau maksimal hanya berbeda } 2 \text { poin) }\end{array}$ \\
\hline \multirow[t]{4}{*}{3} & \multirow[t]{4}{*}{4} & Pencatatan dilakukan oleh peneliti dan anak. \\
\hline & & $\begin{array}{l}\text { Perbandingan pencatatan dan evaluasi hanya } \\
\text { dilakukan selama } 2 \text { kali dari } 4 \text { sesi (sesi } 2 \text { dan } 4 \text { di } \\
\text { tahap 3). }\end{array}$ \\
\hline & & Pembuatan self graph. \\
\hline & & $\begin{array}{l}\text { Reinforcement: } \\
\text { Serupa dengan reward yang diberikan pada tahap } 2 . \\
\text { Hanya saja, reward hanya diberikan jika jumlah } \\
\text { perilaku on-task yang muncul lebih tinggi. } \\
\text { dibandingkan jumlah perilaku on-task pada tahap } \\
\text { sebelumnya. }\end{array}$ \\
\hline \multirow[t]{4}{*}{4} & \multirow[t]{4}{*}{4} & $\begin{array}{l}\text { Anak dapat melakukan self monitoring (sadar saat } \\
\text { off-task dan kembali on-task) tanpa panduan } \\
\text { peneliti. }\end{array}$ \\
\hline & & Evaluasi hanya dilakukan di sesi terakhir. \\
\hline & & Pada setiap sesi, anak membuat self graph. \\
\hline & & Tidak ada reinforcement. \\
\hline
\end{tabular}

\section{Teknik Analisis Data}

Analisis data dilakukan dengan teknik statistik deskriptif menggunakan grafik. Analisis data didapatkan dengan membandingkan durasi mempertahankan perilaku on-task sebelum dan setelah diberikan intervensi.

\section{ANALISIS DAN HASIL}

Berdasarkan hasil baseline selama empat sesi, rata-rata durasi anak menunjukkan perilaku on-task adalah $32,5 \%$ dari total waktu belajar selama 60 menit. Hal-hal yang mendistraksi anak yaitu benda-benda di atas meja, suara tv jika pintu kamar terbuka, suara hewan peliharaan, dan ibu yang harus keluar 
masuk ruangan ketika terdapat pembeli di warung.

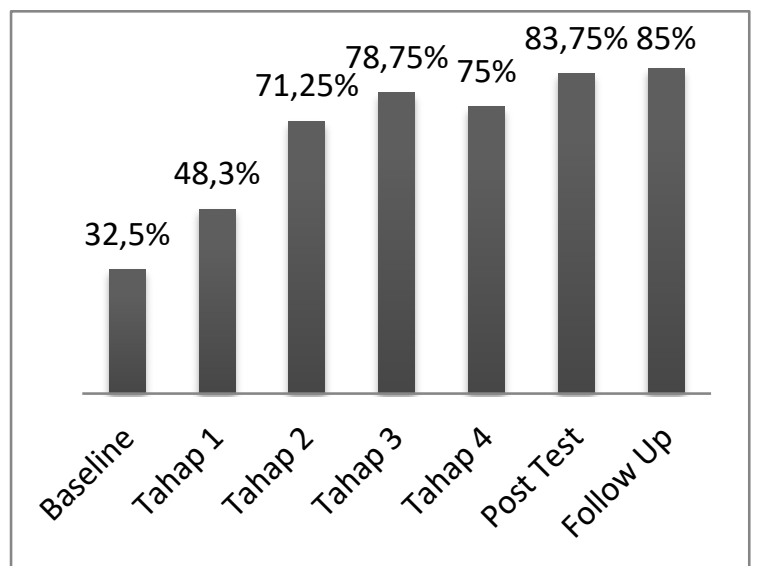

Gambar 1. Perbandingkan persentase rata-rata perilaku on-task.

Anak juga tampak off-task ketika merasa kesal menghadapi tugas yang ia anggap sulit atau merasa lelah. Setelah baseline, peneliti melakukan modifikasi lingkungan dengan menutup pintu kamar selama waktu belajar, menghilangan bendabenda yang mendistraksi dari atas meja belajar anak, serta bekerja sama dengan ibu untuk menutup warung sementara selama waktu belajar.

Peningkatan perilaku on-task anak pun mencapai target yang ditetapkan di awal program, yaitu minimal $60 \%$ dari total durasi belajar 60 menit atau 12 poin perilaku on-task. Saat baseline, rata-rata perilaku on-task pada anak hanya sebatas $32,5 \%$ dari total waktu belajar. Terdapat peningkatan rata-rata perilaku on-task dari tahap 1 hingga tahap 3, yaitu 48,3\% $(9,7$ poin on-task) pada tahap 1, 71,25\% (14,25 poin on-task) pada tahap 2, dan $78,75 \%$ $(15,75$ poin on-task) pada tahap 3 . Sementara itu, rata-rata perilaku on-task pada tahap 4 sedikit lebih rendah dibandingkan tahap 3, yaitu $75 \%$ (15 poin on-task). Saat post-test, rata-rata perilaku on-task meningkat menjadi 83,75\% (16,75 poin) dari total durasi belajar 60 menit.

Follow up dilaksanakan enam minggu setelah sesi terakhir intervensi. Hasil follow up menunjukkan bahwa meski telah tidak lagi diberikan intervensi, A dapat mempertahankan perilaku on-task sebanyak $85 \%$ (17 poin) dari total waktu belajar 60 menit. Berdasarkan hasil wawancara dengan ibu, ibu tetap melaksanakan cara belajar yang diterapkan selama intervensi. Meski belum pernah 100\% menunjukkan perilaku on-task selama 60 menit, anak dapat mempertahankan perilaku on-task lebih dari 15 poin (75\%), mengabaikan suara-suara yang mengganggu, serta lebih giat menyelesaikan tugas menulis jawaban panjang dan matematika.

\section{DISKUSI}

Berdasarkan hasil penelitian, teknik self monitoring dapat meningkatkan perilaku on-task pada anak dengan ADHD. Saat baseline, anak hanya mampu mempertahankan perilaku on-task selama sekitar $25-35 \%$ dari total durasi belajar 60 menit. Dibandingkan kondisi tersebut, anak dapat mempertahankan perilaku on-task di atas $60 \%$ dari total durasi belajar 60 menit secara konsisten sejak tahap dua. Kondisi tersebut bertahan, dan meningkat pada tahap post test, di mana anak dapat mempertahankan perilaku on-task selama sekitar $75-90 \%$ dari total durasi belajar 60 menit.

Hasil tersebut menunjukkan bahwa dengan penerapan teknik self monitoring, anak berhasil meningkatkan kemunculan perilaku on-task sesuai dengan target yang disesuaikan dengan penjabaran Rhode, Jenson, dan Reavis (1992), yaitu anak dikatakan on-task jika ia menunjukkan 
perilaku on-task setidaknya $60 \%$ dari total durasi belajarnya.

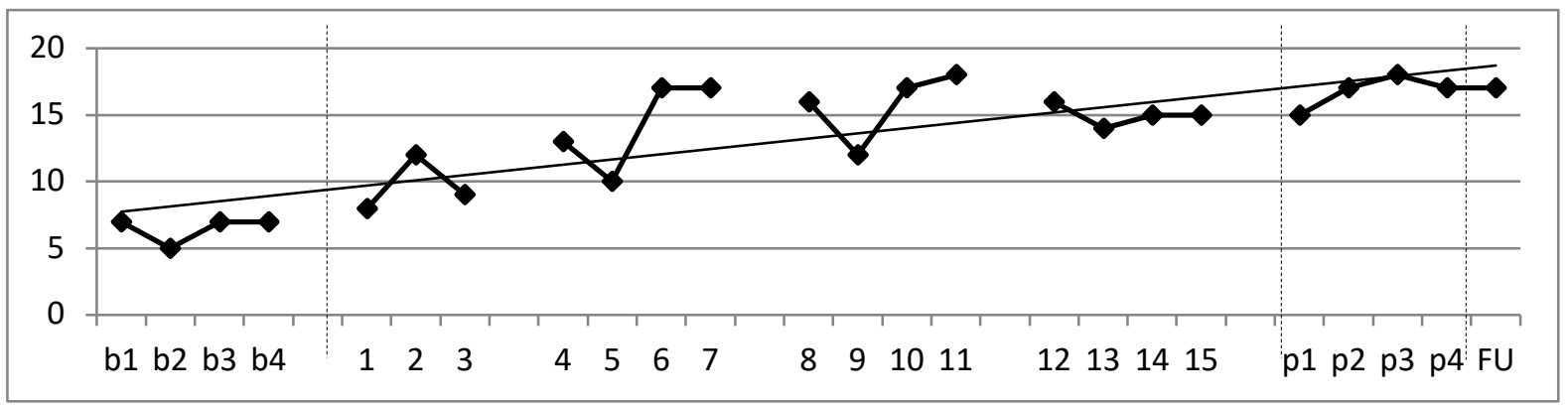

Gambar 2. Perilaku on-task anak selama program self monitoring.

Terdapat beberapa faktor yang memengaruhi peningkatan perilaku on-task pada anak dengan menggunakan teknik self monitoring. Faktor pertama adalah self graph yang dibuat oleh anak dengan bantuan peneliti selama pelaksanaan intervensi. Melalui pembuatan self graph, anak dapat memantau fluktuasi perilaku ontask yang ia tunjukkan pada setiap sesi. Setiap kali grafik menunjukkan penurunan, anak akan berusaha untuk kembali meningkatkan perilaku on-task pada sesi selanjutnya. Hal itu sejalan dengan apa yang dikemukakan oleh DiGangi, Maag, dan Rutherford (2014) bahwa melalui pembuatan self graph, anak dapat memantau perubahan perilaku yang ia lakukan serta membantu meningkatkan motivasi anak untuk melakukan perilaku on-task.

Faktor kedua adalah keinginan yang besar dari anak untuk menunjukkan perilaku on-task selama belajar. Hal tersebut anak tunjukkan dengan menjalankan hasil evaluasi mengenai cara apa saja yang dapat dilakukan untuk mengatasi hal yang mendistraksi anak selama belajar sehingga dapat meningkatkan perilaku on-task pada sesisesi selanjutnya. Saat evaluasi, anak juga proaktif dalam menyampaikan kesulitan dan menyampaikan ide mengenai hal yang dapat dilakukan untuk mengatasi kesulitan yang ia hadapi.
Keinginan yang besar untuk dapat ontask juga anak tunjukkan melalui peningkatan kemampuan regulasi dir saat mengerjakan tipe soal yang membutuhkan usaha yang lebih besar, seperti berhitung dan menulis essay. Awalnya, anak cenderung mudah marah hingga menunjukkan perilaku off-task seperti memukul meja atau menangis dan tidak lagi memperhatikan tugas saat ia harus mengerjakan soal yang membutuhkan usaha lebih besar. Seiring berjalannya intervensi, anak tidak lagi menampilkan sikap mudah menyerah atau marah ketika mengerjakan soal-soal tersebut.

Berdasarkan Axelrod (2014), sikap proaktif anak merupakan salah satu faktor yang berperan dalam pelaksanaan self monitoring. Hal tersebut dapat ditunjukkan dengan adanya kesadaran mengenai perilakunya yang tidak diharapkan serta kemampuan untuk memberikan masukan terhadap perilakunya tersebut. Kesadaran mengenai perilaku anak sendiri dan akurasi anak dalam melakukan evaluasi diri berperan penting dalam pengembangan kemampuan regulasi diri anak (Barkley, 1998).

Faktor ketiga adalah kerjasama yang baik dari orangtua. Pada setiap sesi, ibu selalu menyediakan soal-soal yang akan dikerjakan anak, mendampingi dalam ruangan untuk turut mengobservasi anak dan mengobservasi bagaimana peneliti melakukan intervensi, serta mendiskusikan 
hasil sesi yang telah dilakukan. Ibu juga dilibatkan dalam melakukan evaluasi di akhir tahap 3 dan 4 dengan tujuan untuk menerapkan praktik observasi secara langsung dan mengevaluasi anak berdasarkan apa yang ibu pelajari dari peneliti selama intervensi. Meski tidak terlibat langsung selama intervensi, ayah selalu mendapatkan informasi mengenai sesi dan hasil evaluasi program dari ibu, serta membantu mencetak soal untuk anak. Untuk ke depannya, orangtua juga menyampaikan keinginan untuk menerapkan program self monitoring tanpa didampingi peneliti. Faktor peran orangtua seperti pada penelitian ini sejalan dengan penelitian-penelitian sebelumnya bahwa keterlibatan orangtua yang berperan aktif selama program intervensi cenderung berdampak positif pada pelaksanaan program bagi anak dengan ADHD (Grant, 2012; Power dkk, 2012).

Faktor keempat yang turut mendukung keberhasilan intervensi adalah pemberian reinforcement pada masa awal intervensi. Reinforcement diberikan dalam bentuk stiker yang akan ditukar dengan backup reinforcer berupa consummable reinforcer pada setiap akhir tahap. Keberadaan reinforcement tampak berpengaruh pada tahap 1. Berdasarkan Kazdin (2013), pemberian reinforcement dapat meningkatkan kemunculan perilaku yang diharapkan. Hasil penelitian DuPaul, Weyandt, dan Janusis (2014) pun mendukung bahwa pemberian reinforcement dapat membantu meningkatkan kemunculan perilaku on-task pada anak. Akan tetapi, memasuki tahap 2, yaitu saat anak mulai melakukan pencatatan, motivasi anak untuk meningkatkan perilaku on-task lebih disebabkan oleh fluktuasi self graph yang ia buat dibandingkan reinforcer yang akan ia peroleh.

Selain faktor-faktor yang menunjang efektivitas program, terdapat pula beberapa hal yang berdampak pada tidak optimalnya program. Hal pertama adalah keberadaan adik yang berusia lima tahun di dalam ruangan belajar karena tidak ada orang lain yang dapat mengawasi adik. Faktor kedua yang menjadi hambatan adalah adanya suara-suara yang cukup keras dari lingkungan, seperti suara tetangga dari rumah sebelah, pedagang makanan, suara hujan dan petir, serta suara hewan peliharaan.

Faktor lelah juga menghambat pelaksanaan intervensi. Peneliti mengantisipasi hal tersebut dengan melakukan perubahan pelaksanaan program, yaitu dengan menerapkan waktu istirahat. Dengan demikian, waktu belajar yang dialokasikan selama 1 jam akan dipecah menjadi beberapa sesi dengan penerapan waktu istirahat diantaranya. Dalam pelaksanaannya, waktu belajar pada setiap tahap akan ditingkatkan sebanyak 15 menit sebelum anak diizinkan untuk beristirahat selama 5 menit. Secara rinci, anak akan diizinkan untuk beristirahat setelah belajar selama 15 menit pada tahap pertama, setelah 30 menit pada tahap kedua, setelah 45 menit pada tahap ketiga, dan tidak ada waktu istirahat pada tahap keempat. Perubahan prosedur tersebut juga didasari oleh pernyataan DuPaul, Weyandt, dan Janusis (2011) bahwa pemberian tugas pada anak dengan ADHD dapat dibagi menjadi target yang lebih kecil dan dinaikkan secara bertahap.

\section{SIMPULAN}

Berdasarkan penjabaran hasil intervensi di atas, dapat disimpulkan bahwa program modifikasi perilaku dengan teknik self monitoring efektif untuk meningkatkan perilaku on-task pada anak dengan ADHD usia 9 tahun.

\section{SARAN}

Pada penelitian ini, pelaksanaan program intervensi hanya dilakukan di lingkungan rumah sehingga hasil penelitian kurang dapat digeneralisasi. Penelitian selanjutnya disarankan menggunakan desain penelitian multiple baseline across situation, yaitu tidak hanya pada situasi belajar di rumah tetapi juga di sekolah. 
Selain itu, penelitian selanjutnya disarankan melibatkan partisipan yang lebih banyak sehingga data mengenai efektivitas teknik self monitoring untuk meningkatkan perilaku on-task pada anak dengan ADHD lebih dapat digeneralisasi. Pada penelitian selanjutnya juga disarankan perlu adanya kontrol terhadap hal-hal yang menjadi hambatan, seperti ruangan yang minim dari gangguan orang lain dan pelaksanaan intervensi pada waktu yang lebih tenang dan ideal.

\section{DAFTAR PUSTAKA}

Amato-Zech, N.A., Hoff, K.E., \& Doepke, K.J. (2006). Increasing on-task behavior in the classroom: Extension of self-monitoring strategies. Psychology in the Schools, 43(2), 211-221.

Angelia, F. (2014). Efektivitas metode self monitoring untuk meningkatkan perilaku berorientasi terhadap tugas pada anak kelas 1 sekolah dasar (Tesis). Universitas Indonesia, Depok, Jawa Barat, Indonesia.

Axelrod, M.I. (2014). Using a selfmonitoring intervention to improve students' on-task homework behavior at an after-school program. Journal of Education and Training, 1(2), 58 - 71.

Barkley, R.A. (1997). Behavioral inhibition, sustained attention, and executive functions: Constructing a unifying theory of ADHD. Psychological Bulletin, 121, 65-94.

Barkley, R.A. (1998). Attention deficit hyperactivity disorder; A handbook for diagnosis and treatment. New York: Guilford.

Costa, D.D.S., de Paula, J.J., Junior, A.M.M., Diniz, B.S., Romano-Silve, M.A., Malloy-Diniz, L.F., \& de Miranda, D.M. (2014). ADHD inattentive symptoms mediate the relationship between intelligence and academic performance in children aged 6 - 14. Revista Brasileira de Psiquiatria, 36, 313 - 321.

DiGangi, S.A., Maag, J.W., \& Rutherford Jr., R.B. (2014). Self graphing of ontask behavior: Enhancing the reactive effects of self-monitoring on on task behavior and academic performance. Learning Disability Quarterly, 14(3), 221-230.

DuPaul, G.J., Weyandt, L.L., \& Janusis, G.M. (2014). ADHD in the classroom: Effective intervention strategies. Theory Into Practice, 50, 35 - 42.

Eggett, B. (2013). A review of self management interventions for children with ADHD and implications for education proffesionals. Retrieved from https://digitalcommons.usu.edu/cgi/vie wcontent.cgi article $=1277 \&$ context $=$ gr adreports.

Graham-Day, K.J., Gardner, R., \& Hsin, Y.W. (2010). Increasing on task behaviors of high school students with attention deficit hyperactivity disorder: Is it enough? Education and Treatment of Children, 33(3), 205-211.

Grant, S.M. (2012). Parental involvement in improving academic success for students with ADHD: a comparison of daily behavior report cards and home self-monitoring (Tesis). Diakses dari https://digitalcommons.lsu.edu/cgi/vie wcontent.cgi?referer=https://www.goo gle.co.id/\&httpsredir $=1 \&$ article $=1138$ $\&$ context=gradschool_theses.

Gravetter, F. J. \& Forzano, L. B. (2009). Research methods for the behavioral science $\left(3^{\text {rd }} e d\right)$. Canada: Cengage Learning.

Jembarwati, O. (2015). Self monitoring untuk meningkatkan kesejahteraan emosi peserta didik. Prosiding Seminar 
Psikologi dan Kemanusiaan, Psychology Forum, Universitas Muhammadiyah Malang. Retrieved from

http://mpsi.umm.ac.id/files/file/233238\%20Otih.pdf.

Kazdin, A.E. (2013). Behavior modification in applied settings. Illinois: Waveland Press.

Power, T.J., Mautone, J.A., Soffer, S.L., Clarke, A.T., Marshall, S.A., Sharman, J., Blum, N.J., Glanzman, M., Elia, J., \& Jawad, A.F. (2012). Family-school intervention for children with ADHD: Result of rancomized clinical trial. Journal of Consultation in Clinical Psychology, 80(4), 611-623.

Rhode, G., Jenson, W.R., \& Reavis, H.K. (1992). The tough kid book: Practical classroom management strategies. Longmont: Pacific Northwest Publication.

Ross, P., \& Randolph, J. (2014). Differences between students with and without ADHD on task vigilance under conditions of distraction. Journal of educational research and practice, $4(1), 1-10$.

Saputro, D. (2009). ADHD (Attention Deficit Hyperactivity Disorder). Jakarta: Sagung Seto.

Shapiro, E. S., DuPaul, G. J., \& BradleyKing, K. L. (1998). Self-management as a strategy to improve the classroom behavior of adolescents with ADHD. Journal of Learning Disabilities, 31, 545-555.

Suryanti, D. (2015). Efektivitas selfmonitoring dan self-reward dalam peningkatan disiplin siswa: Penelitian eksperimen kuasi terhadap siswa kelas VIII SMP Negeri 40 Bandung tahun ajaran 2014/2015 (Tesis). Universitas
Pendidikan Indonesia, Bandung, Jawa Barat, Indonesia. 